\title{
Flagellar Antigens of Various Species of the Genus Vibrio and Related Genera
}

\author{
SUMIO SHINODA, REIKO KARIYAMA, MIDORI OGAWA, YOSHIFUMI TAKEDA, AND \\ TOSHIO MIWATANI
}

\begin{abstract}
Department of Hygienic Chemistry, Faculty of Pharmaceutical Sciences, Okayama University, Tsushima, Okayama, and Department of Bacteriology and Serology, Research Institute for Microbial Diseases, Osaka University, Yamada-kami, Suita, Osaka, Japan
\end{abstract}

The antigenicity of purified flagellin prepared from the single polar flagellum of Vibrio parahaemolyticus was found to be common to that of all strains tested, i.e., $V$. alginolyticus, $V$. cholerae, $V$. anguillarum, $V$. piscium, $V$. ichthyodermis, Beneckea natriegens, $B$. campbellii, $B$. nereida, $B$. pelagia, and $B$. neptuna. On the other hand, the antigenicity of purified flagellin prepared from the lateral flagella of $V$. parahaemolyticus was common to that of $V$. alginolyticus but not to that of $B$. campbellii or $B$. neptuna. Some physicochemical properties of flagellin from the single polar flagellum of $V$. parahaemolyticus were found to be similar to those of flagellins from other strains, such as those of $V$. anguillarum and $B$. neptuna.

Vibrio parahaemolyticus possesses lateral flagella in addition to a polar monotrichous flagella in addition to a single polar flagellum under certain culture conditions $(1,3,4,16-18)$. (In previous papers from this laboratory $[8,11-$ 13], lateral flagella were described as peritrichous. However, to distinguish them from the flagella of true peritrichous cells, such as those found in Enterobacteriaceae, we use the term lateral flagella in this paper.) Previously, we reported an antigenic difference between the polar and lateral flagella of $V$. parahaemolyticus $(8,12,13)$. In addition to the antigenic difference, several other different properties of these two flagella were reported. Lateral flagella were produced only on agar plates (3, $17,18)$ and were easily removed from the cells mechanically $(17,18)$, whereas the single polar flagellum was produced either in liquid medium or on agar plates $(3,17,18)$ and could only be removed from the cells by vigorous agitation (7). The single polar flagellum has a sheath-like structure, whereas the lateral flagella do not $(1,7,17,18)$. Moreover, lateral flagella are of the curly type, whereas the single polar flagellum is a normal type $(17,18)$.

This paper reports studies on the distribution of these two kinds of flagellar antigens in various species of the genus Vibrio and related genera.

\section{MATERIALS AND METHODS}

Strains and growth media. The Vibrio and Beneckea strains used are listed in Table 1. (The genus Beneckea is not recognized in Bergey's Manual of Determinative Bacteriology (8th ed.); it is described as a genus of uncertain taxonomic position. In this paper, we adopted the proposal of Baumann et al. [3] for the species of the genus Beneckea.) Modified MOF (MMOF) medium contains the following constituents (grams per liter): Casitone (Difco), 1; yeast extract (Difco), 4.5; tris(hydroxymethyl)aminomethane, 0.5; boric acid, 0.011; ammonium sulfate, 0.5; disodium phosphate, 0.004; ammonium nitrate, 0.0008 ; sodium chloride, 9.7; magnesium chloride, 4.4; sodium sulfate, 1.6 ; potassium chloride, 0.275 ; sodium bicarbonate, 0.08 ; potassium bromide, 0.04 ; strontium chloride, 0.017 ; sodium silicate, 0.002 ; and sodium fluoride, $0.0012 \mathrm{MMOF}$ agar contains $20 \mathrm{~g}$ of agar (Difco) per liter in addition to the above-mentioned components. The medium was adjusted to $\mathrm{pH} 7.5$.

Preparation of crude flagellin solution. Cells grown overnight at $25 \mathrm{C}$ on plates containing $20 \mathrm{ml}$ of MMOF agar were suspended in $2 \mathrm{ml}$ of $0.01 \mathrm{M}$ phosphate buffer $\left(\mathrm{Na}_{2} \mathrm{HPO}_{4}-\mathrm{K}_{2} \mathrm{HPO}_{4}, \mathrm{pH}\right.$ 7.0) containing $0.9 \% \mathrm{NaCl}$ and heated at $65 \mathrm{C}$ for $10 \mathrm{~min}$ to solubilize the flagella. The mixture was centrifuged at $9,000 \times g$ for $15 \mathrm{~min}$, and the supernatant was used as the crude flagellin solution. Cells of $V$. cholerae were mixed with $3 \%$ phenol and then dialyzed before being heated.

Preparation of purified flagellin. The procedures used for purification of flagella were essentially as described previously $(7,13)$. Cells were grown on MMOF agar at $25 \mathrm{C}$ overnight, and then their flagella were removed by vigorous agitation in a Waring blendor $(8,000 \mathrm{rpm}$ for $5 \mathrm{~min})$. The flagella from each strain were purified by differential centrifugation, treatment with diethylaminoethyl-cellulose, and zone electrophoresis on Pevikon C-870, as described previously $(7,13)$. The flagellins were then prepared from the purified flagella and filtered through a Sephadex G-100 column. Each type flagellin was subjected to hydroxyapatite column chromatography. 


\begin{tabular}{|c|c|c|}
\hline Organism & Strain no. & $\begin{array}{l}\text { Type of } \\
\text { flagella- } \\
\text { tion of } \\
\text { cells on } \\
\text { solid me- } \\
\text { dium }\end{array}$ \\
\hline $\begin{array}{l}\text { Vibrio parahaemolyticus } \\
\text { V. alginolyticus } \\
\text { V. cholerae } \\
\text { V. cholerae } \\
\text { V. cholerae eltor } \\
\text { V. cholerae eltor } \\
\text { Vibrio sp. } \\
\text { Vibrio sp. } \\
\text { V. anguillarum } \\
\text { V. anguillarum } \\
\text { V. anguillarum } \\
\text { V. piscium } \\
\text { V. ichthyodermis } \\
\text { Beneckea natriegens } \\
\text { B. campbellii } \\
\text { B. nereida } \\
\text { B. pelagia } \\
\text { B. neptuna }\end{array}$ & $\begin{array}{l}\text { WP-1 } \\
\text { H2-17 } \\
\text { Original 124 } \\
\text { Variant 41 } \\
\text { Original 1973 } \\
\text { Variant p1418 } \\
\text { NCTC } 30 \text { (III) }^{c} \\
\text { NCTC 4716 (VI) } \\
\text { NCMB 6 } \\
\text { NCMB } 828 \\
\text { NCMB } 829 \\
\text { NCMB 571 } \\
\text { NCMB 571 } \\
\text { ATCC 14048 } \\
\text { ATCC 25920 } \\
\text { ATCC 25917 } \\
\text { ATCC 25916 } \\
\text { ATCC 25919 }\end{array}$ & $\begin{array}{l}M+\mathbf{L}^{a} \\
\mathbf{M}+\mathbf{L} \\
\mathbf{M}^{b} \\
\mathbf{M} \\
\mathbf{M} \\
\mathbf{M} \\
\mathbf{M} \\
\mathbf{M} \\
\mathbf{M} \\
\mathbf{M} \\
\mathbf{M} \\
\mathbf{M} \\
\mathbf{M} \\
\mathbf{M} \\
\mathbf{M}+\mathbf{L} \\
\mathbf{M} \\
\mathbf{M} \\
\mathbf{M}+\mathrm{L}\end{array}$ \\
\hline
\end{tabular}

Preparation of anti-flagellin antiserum. A solution of about $200 \mu \mathrm{g}$ of purified flagellin in $5 \mathrm{ml}$ of $0.01 \mathrm{M}$ phosphate buffer ( $\mathrm{pH} 7.0$ ) was emulsified with an equal volume of Freund incomplete adjuvant (Difco). The emulsion was inoculated intramuscularly into rabbits weighing 2.5 to $3 \mathrm{~kg}$. After 2 weeks, the rabbits were again inoculated with the same amount of emulsion. Two additional intravenous injections of $2 \mathrm{ml}$ of flagellin $(100 \mu \mathrm{g})$ were then given at intervals of 1 week; antiserum was obtained 1 week after the final immunization.

Gel diffusion test. The plate method of Ouchterlony (9) was used for the gel diffusion test with $0.7 \%$ agar (Noble; Difco) in $0.01 \mathrm{M}$ tris(hydroxymethyl)aminomethane-hydrochloride buffer (pH 7.0). Samples were put into the wells, and the plates were placed in a humidified incubator at $37 \mathrm{C}$.

Assay of protein and phosphate ion concentration. Protein concentration was determined by the method of Lowry et al. (5), and the phosphate ion concentration was determined by the method of Baginski et al. (2).

Analysis of the amino acid composition of flagellin. About $500 \mu \mathrm{g}$ of flagellin was hydrolyzed with 2 $\mathrm{ml}$ of $6 \mathrm{~N}$ hydrochloride at $105 \mathrm{C}$ for $12 \mathrm{~h}$ in a sealed glass tube. The mixture was dried in a vacuum evaporator, the residue was dissolved in $2 \mathrm{ml}$ of 0.2

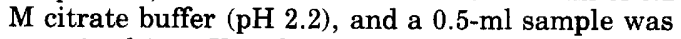
examined in a Hitachi amino acid analyzer, model KLA-5.

\section{RESULTS}

Antigenicities of flagellins from various species of the genera Vibrio and Beneckea. Motile strains of $V$. parahaemolyticus, of the six species of the genus Vibrio, and of the five species of the genus Beneckea listed in Table 1 were selected on soft-agar media to test the antigenicities of their flagellins. These strains were grown on MMOF agar plates, and crude flagellin solutions were prepared from them and subjected to the gel diffusion test, using antisera against flagellin of $V$. parahaemolyticus WP-1.

Antiserum against purified flagellin of single polar flagella (M flagellin) of $V$. parahaemolyticus WP-1 gave a common precipitin line with the crude flagellin solutions of all strains examined, indicating that all 18 strains have antigenically homogeneous $M$ flagellin. Some of the results are shown in Fig. 1. It can be seen that two strains of $V$. cholerae, $V$. anguillarum, $B$. neptuna, and $B$. natriegens formed a common precipitin line against the anti-M flagellin antiserum of $V$. parahaemolyticus WP-1.

Among the 18 strains examined, $V$. parahaemolyticus, $V$. alginolyticus, $B$. campbellii, and $B$. neptuna formed lateral flagella when grown on solid media, in addition to a single polar flagellum $(3,4,13,17,18)$. The antigenicities of crude flagellin solutions of these strains were examined in the agar gel diffusion test with antiserum against purified lateral flagellin (L flagellin) of $V$. parahaemolyticus WP-1. $V$. alginolyticus contained L flagellin antigeni-

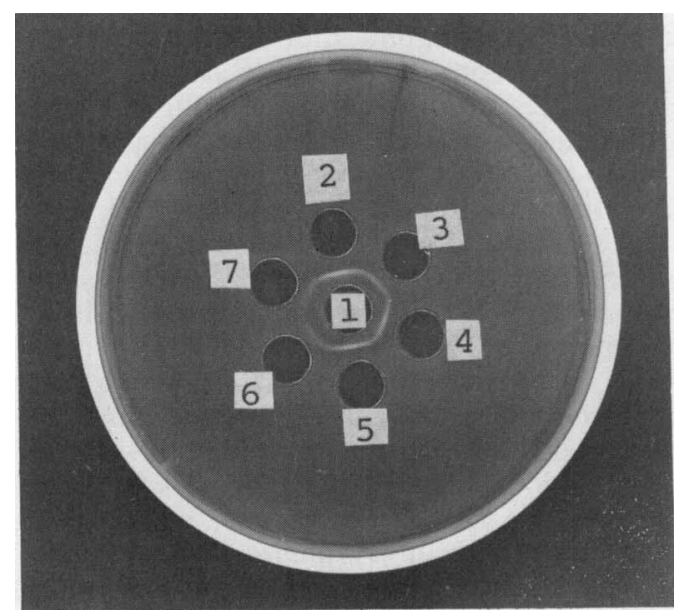

FIG. 1. Antigenic homogeneity of single polar flagella in the gel diffusion test. Antiserum against single polar flagellum of $V$. parahaemolyticus WP-1 was placed in the center well (1). The other wells contained crude flagellin solutions from (2) $V$. parahaemolyticus WP-1, (3) $V$. cholerae original 124 , (4) $V$. cholerae variant 41 , (5) $V$. anguillarum NCMB 829, (6) B. neptuna ATCC 25919, and (7) B. natriegens ATCC 14048. 
cally identical to $V$. parahaemolyticus L flagellin, whereas crude flagellin solutions of $B$. campbellii and $B$. neptuna did not form any precipitin line with anti-L flagellin antiserum of $V$. parahaemolyticus WP-1 (Fig. 2). Moreover, L flagellin of $B$. campbellii and $B$. neptuna did not react with heterologous anti-L flagellin antiserum (Fig. 3).

These results indicate that the antigenicity of the single polar flagellum of various species of the genera Vibrio and Beneckea, including $V$. parahaemolyticus, $V$. alginolyticus, $V$. cholerae, $V$. anguillarum, $V$. piscium, $V$. ichthyodermis, $B$. natriegens, $B$. campbellii, $B$. nereida, $B$. pelagia, and $B$. neptuna, is homologous, whereas the antigenicities of lateral flagella of the different species all differ from each other, except for the lateral flagella of $V$. parahaemolyticus and $V$. alginolyticus, which share the same antigenicity.

Some physicochemical properties of flagellins from various species of the genera Vibrio and Beneckea. When the purified flagellin was subjected to hydroxyapatite column chromatography, two distinct peaks were obtained with the flagellins of $V$. parahaemolyticus and $B$. neptuna (Fig. 4A and C). On the other hand, the flagellin of $V$. anguillarum gave a single peak upon hydroxyapatite column chromatography (Fig. 4B). On the basis of our previous data (13), the peak eluted with the lower concentration of phosphate ion is derived from lateral flagella, and that eluted with the higher

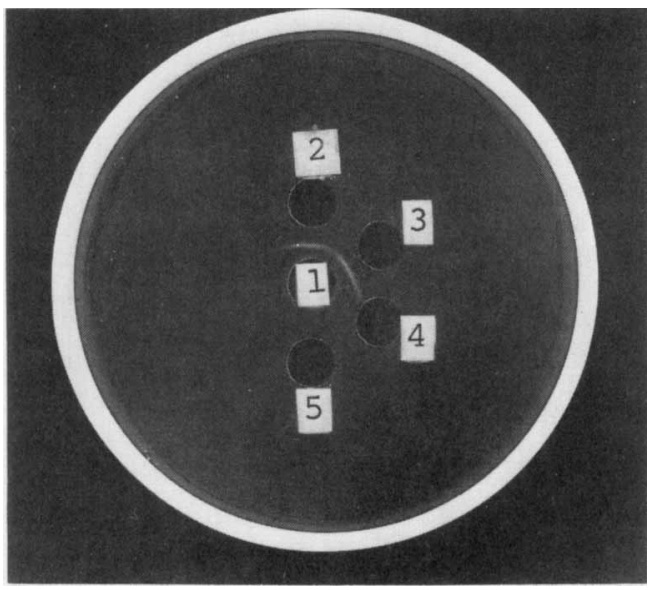

FIG. 2. Antigenic homogeneity of lateral flagella in the gel diffusion test. Antiserum against lateral flagella of $V$. parahaemolyticus WP-1 was placed in the center well (1). The other wells contained crude flagellin solutions from (2) V. parahaemolyticus WP1 , (3) $V$. alginolyticus $H 2-17$, (4) B. neptuna ATCC 25919 , and (5) B. campbellii ATCC 25920.

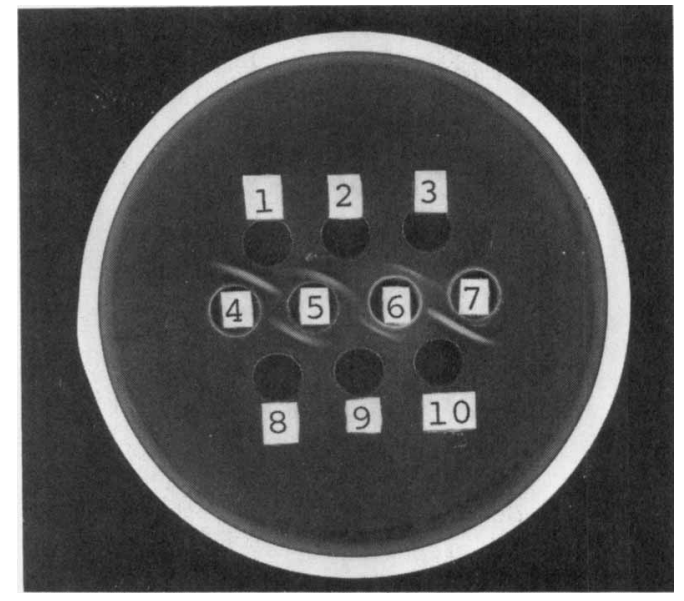

FIG. 3. Gel diffusion test on flagellins from lateral flagella. Antiserum against lateral flagella of $V$. parahaemolyticus WP-1 was placed in wells 4 and 7, against those of B. neptuna ATCC 25919 in well 5, and against $B$. campbellii ATCC 25920 in well 6. Flagellin of $V$. parahaemolyticus WP-1 was placed in wells 1 and 10 , that of $B$. neptuna was placed in wells 2 and 8, and that of B. campbellii ATCC 25920 was placed in wells 3 and 9.

concentration is derived from single polar flagella.

To determine the molecular weights of the flagellins from single polar flagella of these three strains, the flagellins were subjected to Sephadex G-100 gel filtration. All of these flagellins eluted in the same position, indicating that they have similar molecular weights (Fig. 5). Previously we reported that the molecular weight of flagellin from single polar flagella of $V$. parahaemolyticus is about 40,000 (11), so it is concluded that the molecular weights of the flagellins of single polar flagella of $V$. anguillarum and $B$. neptuna are also about 40,000 .

Table 2 shows the amino acid compositions of the flagellins from single polar flagella of $V$. parahaemolyticus WP-1, $V$. anguillarum NCMB 829, and B. neptuna ATCC 25919. The amino acid compositions of these three flagellins are, in general, very similar.

From these results it is concluded that single polar flagella of various species of Vibrio and Beneckea have not only homologous antigenicity but also similar physicochemical properties.

\section{DISCUSSION}

In this work the antigenicities of single polar flagella and lateral flagella of various species of the genera Vibrio and Beneckea were studied. 

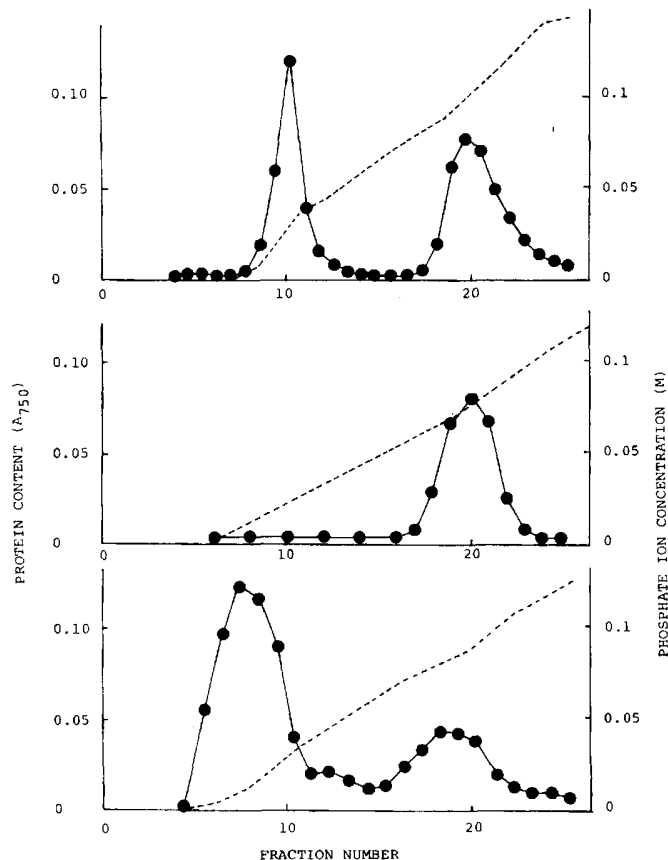

FIG. 4. Hydroxyapatite column chromatography of flagellin. Purified flagellin was chromatographed on a hydroxyapatite column. (A) Flagellin of $V$. parahaemolyticus WP-1, (B) flagellin of $V$. anguillarum NCMB 829, and (C) flagellin of $B$. neptuna ATCC 25919. Protein content (O) was measured by the method of Lowry et al. (5).---, Concentration of phosphate ion.

It was found that the single polar flagellum of $V$. parahaemolyticus had the same antigenicity as that of the single polar flagella of strains of $V$. alginolyticus, $V$. cholerae, $V$. anguillarum, $V$. piscium, $V$. ichthyodermis, $B$. natriegens, $B$. campbellii, $B$. nereida, $B$. pelagia, and $B$. neptuna.

Although it has been reported that $V$. parahaemolyticus and $V$. alginolyticus possess the same $\mathrm{H}$ antigen $(6,15)$, several workers have concluded that there is no $\mathrm{H}$ antigen common to different species of the genus Vibrio $(10,14,15)$. Terada (15) reported that the $\mathrm{H}$ antigen of $V$. parahaemolyticus was different from that of $V$. cholerae, $V$. anguillarum, and some strains of Vibrio species that do not agglutinate with anti- $V$. cholerae antiserum (so-called NAG vibrio). Sakazaki et al. (10) also reported that there is an $\mathrm{H}$ antigen common to different strains of $V$. cholerae and some Vibrio species but that this antigen is not homologous with the $\mathrm{H}$ antigen of $V$. parahaemolyticus and $V$. anguillarum. Smith (14) reported no evidence for an $\mathrm{H}$ antigen common to $V$. cholerae and some Vibrio species described by Sakazaki et al. (10). These workers reached their conclu-

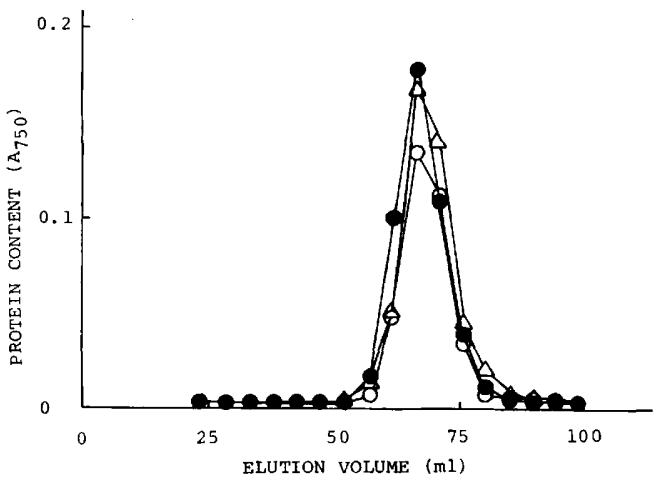

FIG. 5. Sephadex G-100 gel filtration of flagellins. Flagellins prepared from purified flagella by heating at $65 \mathrm{C}$ for $3 \mathrm{~min}$ were applied to a Sephadex G-100 column (2 by $100 \mathrm{~cm})$, and the column was eluted with $0.01 \mathrm{M}$ phosphate buffer ( $\mathrm{pH}$ 7.0). Protein content was measured by the method of Lowry et al. (5). - Flagellin of $V$. parahaemolyticus WP-1; $\triangle$, flagellin of $V$. anguillarum NCMB 829; and $\bigcirc$, flagellin of B. neptuna ATCC 25919.

TABLE 2. Amino acid compositions of flagellins of single polar flagella

\begin{tabular}{|c|c|c|c|}
\hline \multirow[b]{2}{*}{ Amino acid } & \multicolumn{3}{|c|}{ Amt (mol/mol of protein) } \\
\hline & $\begin{array}{c}\text { Vibrio } \\
\text { parahae- } \\
\text { molyticus } \\
\text { WP-1 }\end{array}$ & $\begin{array}{l}\text { V. anguil } \\
\quad \text { larum } \\
\text { NCMB } 828\end{array}$ & $\begin{array}{c}\text { Beneckea } \\
\text { neptuna } \\
\text { ATCC } \\
25919 \\
\end{array}$ \\
\hline Lysine & 21.9 & 19.1 & 21.5 \\
\hline Histidine & 2.3 & 1.7 & 1.3 \\
\hline Arginine & 12.9 & 13.7 & 12.5 \\
\hline $\begin{array}{l}\text { Aspartic } \\
\text { acid }\end{array}$ & 58.4 & 62.3 & 62.0 \\
\hline Threonine & 21.9 & 28.9 & 22.3 \\
\hline Serine & 40.9 & 26.3 & 39.2 \\
\hline $\begin{array}{l}\text { Glutamic } \\
\text { acid }\end{array}$ & 58.0 & 48.3 & 55.0 \\
\hline Proline & 0 & 0 & 0 \\
\hline Glycine & 35.8 & 42.1 & 35.0 \\
\hline Alanine & 44.6 & 41.2 & 42.6 \\
\hline Cystine & 0 & 0 & 0 \\
\hline Valine & 17.1 & 22.1 & 20.8 \\
\hline Methionine & 8.7 & 10.3 & 7.9 \\
\hline Isoleucine & 15.8 & 21.2 & 17.8 \\
\hline Leucine & 27.3 & 26.7 & 27.1 \\
\hline Tyrosine & 5.8 & 4.0 & 5.4 \\
\hline $\begin{array}{l}\text { Phenylala- } \\
\text { nine }\end{array}$ & 7.6 & 10.8 & 8.2 \\
\hline
\end{tabular}

sions from the results of $\mathrm{H}$ agglutination tests on the cells; they did not apply the gel diffusion technique used in this work. We assume that their data indicating that there is no common $\mathbf{H}$ antigen was due to the low titer of antisera, because antigen used for immunization contained very little flagellar protein. It is also probable that even the antiserum with the high titer against $V$. cholerae flagella does not react with $V$. parahaemolyticus since it has a sheath- 
like structure on its single polar flagellum $(1,7,17,18)$.

The physicochemical properties of the flagellins of single polar flagella suggested that flagella of various species of the genera Vibrio and Beneckea possess the same protein moiety and that they may share the same antigen determinants.

It is interesting that, among the lateral flagella of the different species examined, only $V$. parahaemolyticus and $V$. alginolyticus have homogeneous antigenicity. Each species seems to possess its own specific antigenicity. If so, it may be possible to identify a bacterium by using the specific antiserum against its lateral flagella. Experiments on this are now in progress in our laboratory.

\section{ACKNOWLEDGMENT}

We would like to express our thanks to M. Makita for valuable discussion.

\section{REPRINT REQUESTS}

Address reprint requests to: Sumio Shinoda, Department of Hygienic Chemistry, Faculty of Pharmaceutical Sciences, Okayama University, Tsushima, Okayama, Japan.

\section{LITERATURE CITED}

1. Allen, R. D., and P. Baumann. 1971. Structure and arrangement of flagella in species of the genus Beneckea and Photobacterium fischeri. J. Bacteriol. 107:295-302.

2. Baginski, E. S., P. P. Foa, and B. Zak. 1967. Microdetermination of inorganic phosphate, phospholipids and total phosphate in biological material. Clin. Chem. 13:326-332.

3. Baumann, P., L. Baumann, and M. Mandel. 1971. Taxonomy of marine bacteria: the genus Beneckea. J. Bacteriol. 107:268-294.

4. Baumann, P., L. Baumann, and J. L. Reichelt. 1973. Taxonomy of marine bacteria: Beneckea parahaemolytica and Beneckea alginolytica. J. Bacteriol. 113:1144-1155.

5. Lowry, O. H., N. H. Rosebrough, A. L. Farr, and R. J. Randall. 1951. Protein measurement with the Folin phenol reagent. J. Biol. Chem. 193:265-275.
6. Miwatani, T., and S. Shinoda. 1971. Flagellar antigen of Vibrio alginolyticus. Biken J. 14:389-394.

7. Miwatani, T., S. Shinoda, and T. Fujino. 1970. Purification of monotrichous flagella of Vibrio parahaemolyticus. Biken J. 13:149-155.

8. Miwatani, T., S. Shinoda, E. Yabuuchi, T. Honda, and Y. Takeda. 1975. Existence of polar and peritrichous flagella and their antigenic difference in Vibrio parahaemolyticus, p. 684-690. In T. Hasegawa (ed.), Proc. 1 st Intersect. Cong. IAMS, vol. 1. Science Council of Japan, Tokyo.

9. Ouchterlony, O. 1949. Antigen-antibody reaction in gels. Acta Pathol. Microbiol. Scand. 26:507-515.

10. Sakazaki, R., K. Tamura, C. Z. Gomez, and R. Sen. 1970. Serological studies on the cholera group of vibrios. Jpn. J. Med. Sci. Biol. 23:13-20.

11. Shinoda, S., T. Miwatani, and T. Fujino. 1970. Antigens of Vibrio parahaemolyticus. II. Existence of two different subunits in the flagella of Vibrio parahaemolyticus and their characterization. Biken J. 13:241-247.

12. Shinoda, S., T. Miwatani, T. Honda, and Y. Takeda. 1974. Antigenicity of flagella of Vibrio parahaemolyticus, p. 193-198. In T. Fujino, G. Sakaguchi, R. Sakazaki, and $Y$. Takeda (ed.), International Symposium on Vibrio parahaemolyticus. Saikon Publishing Co., Tokyo.

13. Shinoda, S., T. Honda, Y. Takeda, and T. Miwatani. 1974. Antigenic difference between polar monotrichous and peritrichous flagella of Vibrio parahaemolyticus. J. Bacteriol. 120:923-928.

14. Smith, H. J., Jr. 1974. Antibody responses in rabbits to injections of whole cells, flagella, and flagellin preparations of cholera and noncholera vibrios. Appl. Microbiol. 27:375-378.

15. Terada, Y. 1968. Serological studies of Vibrio parahaemolyticus. II. Flagellar antigens. Jpn. J. Bacteriol. 23:767-771.

16. Yabuuchi, E., A. Ohyama, T. Miwatani, and Y. Takeda. 1973. Vibrio parahaemolyticus: polar monotrichous or peritrichous? Jpn. J. Bacteriol. 28:58.

17. Yabuuchi, E., T. Miwatani, Y. Takeda, and M. Arita. 1974. Flagellar morphology of Vibrio parahaemolyti. cus, p. 163-168. In T. Fujino, G. Sakaguchi, R. Sakazaki, and Y. Takeda (ed.), International Symposium on Vibrio parahaemolyticus. Saikon Publishing Co., Tokyo.

18. Yabuuchi, E., T. Miwatani, Y. Takeda, and M. Arita. 1974. Flagellar morphology of Vibrio parahaemolyticus (Fujino et al.) Sakazaki, Iwanami and Fukumi 1963. Jpn. J. Microbiol. 18:295-305. 